\title{
CHARACTERISTICS OF A DIESEL ENGINE WITH A CERAMIC COATED PISTON HEAD
}

In this age of fuel problems, the improvement in thermal efficiency of an engine is very important. One of the ways leading to this aim consists in reducing heat losses by the application of heat-insulating coatings on the elements of the combustion chamber. The article deals with the effect of the piston head heat-insulation on a Diesel engine running indicators and presents the results of the tests.

\section{Introduction}

From the Analysis of the combustion engine heat balance it may be concluded that the thermal insulation of a combustion chamber should reduce energy losses caused by heat radiation, convection and flow to the cooling agent. Consequently, the improvement of engine watt-hour efficiency as well as the increase of life and resistance of its elements is expected.

Many centres, including Cracow University of Technology [3, $4,9,10,11]$, are engaged in research into this matter, achieving different results. Both improvement and deterioration of engine running economy were noted in the case of heat insulated elements participating in heat exchange. Equally, divergent results are reported for exhaust gas toxicity.

Mostly, for insulation of combustion chamber elements, ceramic coatings made of $\mathrm{ZrO}_{2}$ solid solutions partly stabilised with $\mathrm{Y}_{2} \mathrm{O}_{3}$, $\mathrm{CaO}$, and $\mathrm{MgO}$ oxides or with rare earths mixture $\left(\mathrm{Ln}_{2} \mathrm{O}_{3}\right)$ are used. Apart from a low thermal conduction, they are marked with variable heat loading resistance.

Analysing the share of different surface elements creating a combustion chamber in this phase of the cycle when the maximum heat quantity is generated (i.e. close by the top dead centre), it is possible to state that the share of a cylinder wall in total heat exchange surface is 10 to $30 \%$. Consequently, the piston head and the corresponding head base surface are supposed to play the key role in heat transmission to the cooling agent. The above statements allow to conclude that the use of heat insulation on the piston head will be of great importance for the engine characteristics.

\section{Experimental Tests}

The investigation was carried out using a monocylinder normally aspirated engine with direct fuel injection to an open, toroidal combustion chamber, located in the piston. The nominal rotational speed of the examined engine (SB.3.1 type) was $2200 \mathrm{rpm}$. The engine was cooled with a fluid in circulation forced by a water pump.

The engine characteristics were examined by installing successively four different pistons: a standard one made of aluminium alloy (AK-12) and three others with heat insulating ceramic coatings. The coatings of zirconium dioxide $\left(\mathrm{ZrO}_{2}\right)$ partially stabilised with yttrium trioxide $\left(\mathrm{Y}_{2} \mathrm{O}_{3}\right)$ were deposited by a plasma spraying method on the piston heads. The ceramic coatings differed in thickness and porosity. Therefore, different values of heat resistance and thermal conductance coefficients were noted. Heat resistance of a coating is decisive in modifying heat properties of a piston head. Consequently, for the analysis of engine characteristics, the coating heat resistance was assumed as the value determining the heat insulation of the piston.

The engine was tested on a stand equipped with an electric brake and measuring devices enabling to determine values of the following characteristics: operating (power $N_{e}$ and moment $M_{o}$ ), economic (fuel consumption per hour and per unit) as well as the parameters connected with working medium pressure run in the engine cylinder, fuel pressure before the injector and before displacement of the injector needle depending on the crank angle. Concentration of toxic exhaust gas constituents: nitric oxides $\left(\mathrm{NO}_{\mathrm{x}}\right)$, hydrocarbons ( $\mathrm{HC})$, carbon monoxide (CO) and smokiness, was examined too.

\section{Results and discussion}

Changes of combustion indicators, determined by a thermodynamic analysis of indicator diagrams, depending on heat resistance of the ceramic coatings deposited on the piston heads, at a rotational speed $n=2200 \mathrm{rpm}$ and at the mean pressure $p_{e}=0,6 \mathrm{Mpa}$, are presented in Figs. 1 and 2.

In the case of the pistons with ceramic-coated heads, self-ignition delay is smaller than in the case of the standard pistons. It can be explained by a higher temperature in the combustion chamber

\footnotetext{
* Andrzej Mruk

Institute of Automobiles and Internal Combustion Engines, Cracow University of Technology, 31-864 Krakow, al. Jana Pawła II nr 37, Poland, Tel.: + 48/126283518, Fax.:+ 48/126283520,E-mail:mruk@mech.pk.edu.pl
} 
during injection of fuel charge and, thereby, better evaporation of fuel. However, the lowest values of a self-ignition period were obtained for ceramics marked by lower heat resistance values and, consequently, lower temperatures. It can be presumed that a large increase of temperature results in reducing the speed of fuel injection to the combustion chamber and its prolongation caused by the increase of atomiser leakage. In consequence, the advantageous effect of better evaporation is partly destroyed. The increase of leakage may occur when the fuel viscosity decreases or when the injector guide clearance increases due to a higher temperature.
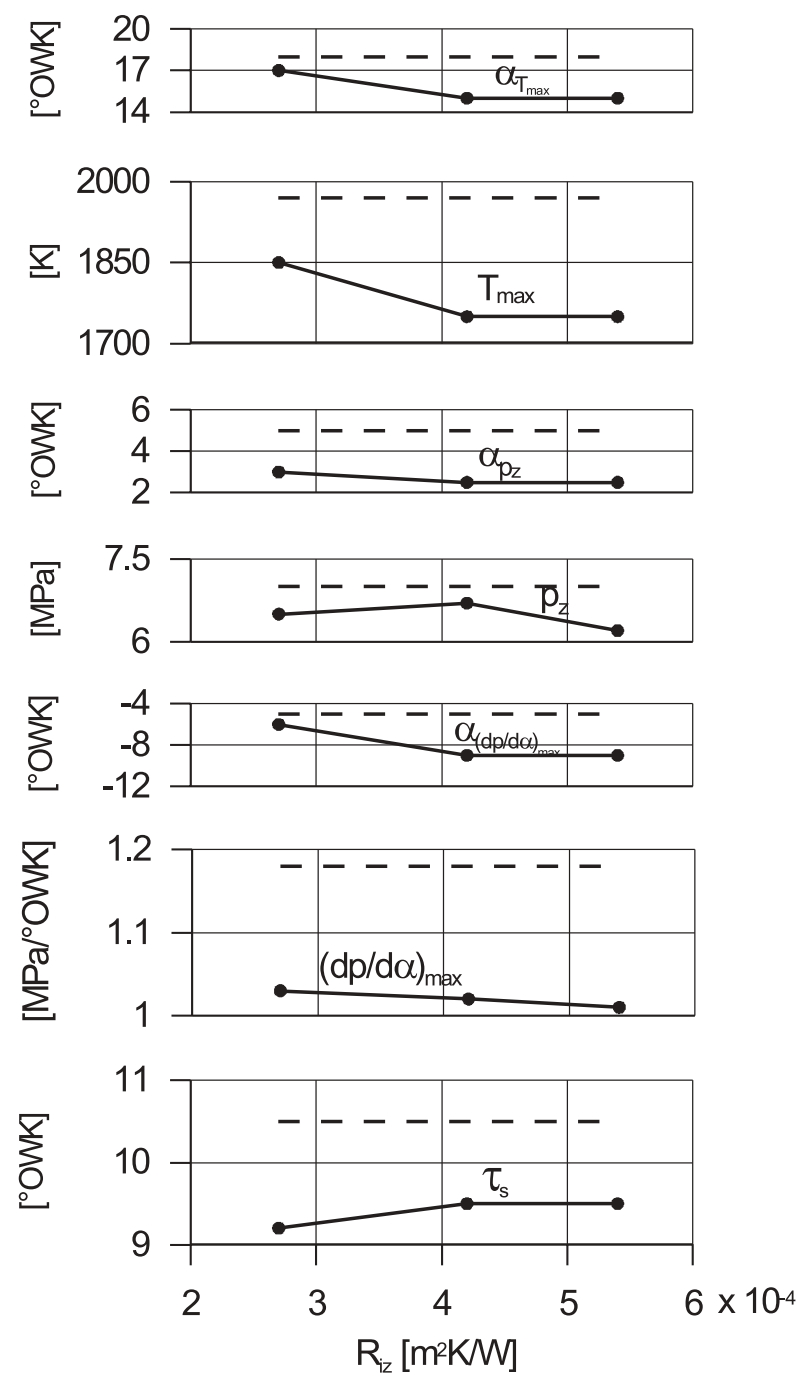

Fig. 1. Influence of heat resistance of insulating coatings on piston heads on combustion indicators; $n=2200 \mathrm{rpm}, p_{e}=0.6 \mathrm{MPa}$. Broken line - values for piston without coating.

The above hypothesis seems to be confirmed by the results of Dickey's investigation [5] where a reduction of injection pressure was found in the case of applying heat insulation in the combustion chamber.
Maximum temperatures in the cylinder determined on the basis of thermodynamic analysis of indicator diagrams decrease when heat resistance of the coatings increases. The reduction of maximum temperature values in the cylinder is accompanied by a reduction of maximum combustion pressure values, although the influence of heat resistance is not unambiguous here. Lower values of maximum temperature and pressure in the cylinder can be explained by reduction of air mass supplied to the cylinder of a normally aspirated engine resulting in incomplete deficient combustion. The rise of temperature on the inlet channel and combustion chamber surfaces causes the reduction of density and, consequently, of aspirated air mass, particularly during the period of closing the inlet valve.
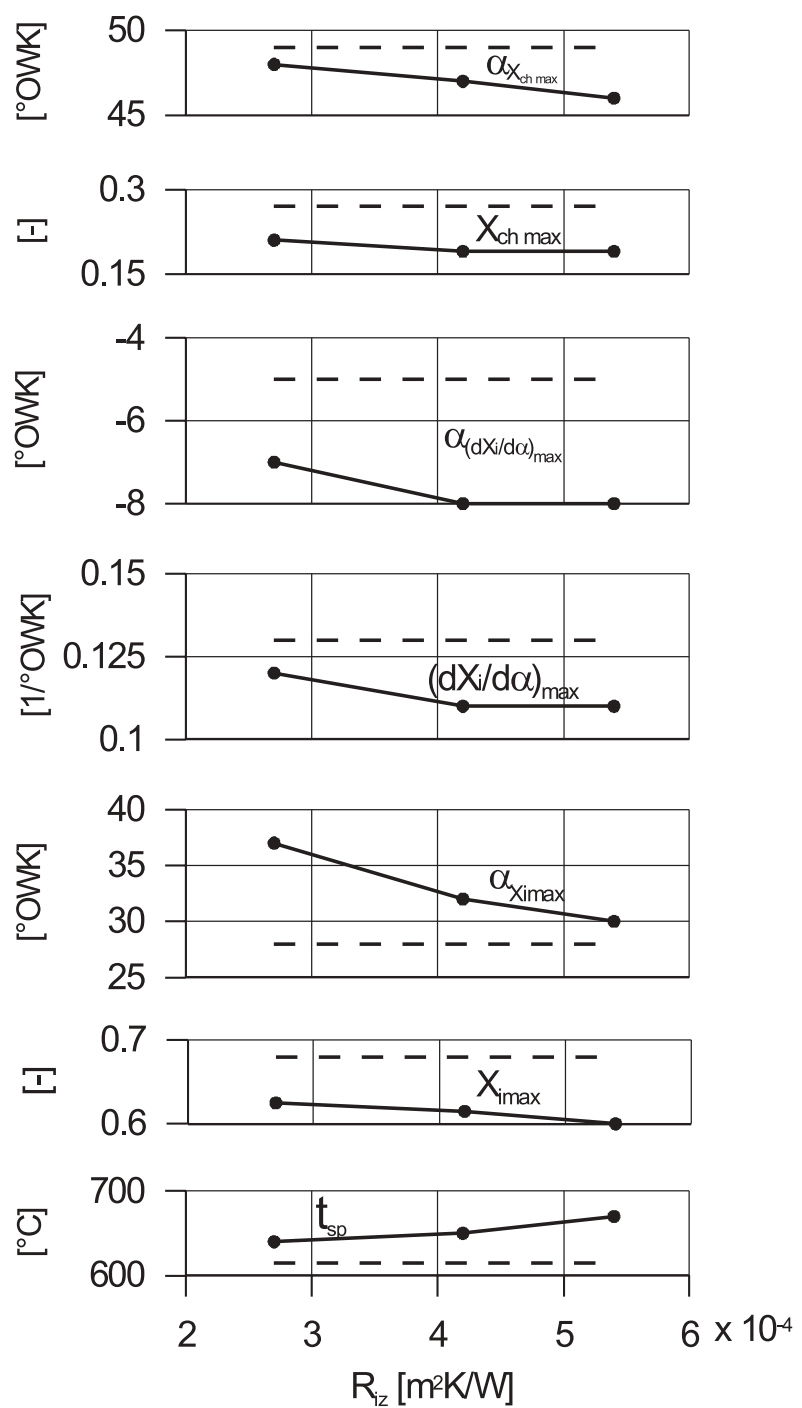

Fig. 2 Influence of heat resistance of insulating coatings on piston heads on combustion indicators; $n=2200 \mathrm{rpm}, p_{e}=0.6 \mathrm{MPa}$. Broken line-values for piston without coating.

The reduction of maximum combustion pressure may come also from the prolongation of combustion time. Alkidas [1,2] reports that the combustion time in an engine with a heat insulated chamber 
may grow due to incorrect mixing of fuel and air in the combustion chamber as a result of reduced air mass and lower speed of fuel injection to the chamber as well as of elongated injection time. This interpretation seems to be convincing. Moreover, as shown in Fig. 1, the application of heat insulating coatings resulted in approximating maximum values of combustion and temperature pressure to the T.D.C. It corresponds roughly to the differences in angular variation of self-ignition delay.

The formation of the value of combustion pressure growing maximum speed $(d p / d \alpha)_{\max }$ by the action of heat resistance of ceramic coatings on the piston heads is convergent with the variation of maximum pressure and temperature in the cylinder.

Maximum values of the heat evolution indicator and of maximum speed of heat absorption by a working agent $\left(d X_{i} / d \alpha\right)_{\max }$ are lower in case of applying heat-insulating coatings. Also, when the heat resistance of ceramic coatings increases, the values of these indicators slightly decrease. It is probably due to incomplete and deficient combustion of fuel as a result of smaller air mass supplied to the cylinder. In case of applying the ceramic coatings, maximum values of $X_{i}$ are located nearer by the T.D.C., whereas maximum values of $d X_{i} / d \alpha$ occur further from the T.D.C. It is the consequence of a shorter self-ignition delay period as well as a better evaporation and heating of the fuel. Such formation of these values is advantageous considering the distribution of heat evolution during the cycle.

The value of determined maximum coefficient of cooling losses $X_{c h}$ is, as expected, lower in case of applying the coatings. Reduced carrying away of heat from the agent to the combustion chamber walls results in the increasing exhaust gas mean temperature.

Figs. 3 and 4 show changes of the engine working parameters depending on heat resistance of the ceramic coatings deposited on the piston heads for a rotational speed $n=2200 \mathrm{rpm}$ and two different values of fuel consumption per hour, corresponding to low and high engine loadings.

As it is visible, fuel consumption per unit for an engine with the heat-insulated pistons is higher than in case of a standard engine. Only for the piston marked by the highest coefficient of heat resistance, fuel consumption was slightly lower within the range of low engine loading. These results meet other results reported [1, 5, 8, 13]. Generally, the level of exhaust gas smokiness was, at low engine loading, higher for insulated pistons, except for the piston with the highest heat resistance coefficient, where the exhaust gas smokiness was slightly lower when compared with a standard piston. In this case, it may be the effect of improving diffusive mixing efficiency as well as of better utilisation of the air during combustion process, but also of more intense oxidation of soot at higher temperatures. This conclusion could be confirmed by results achieved at higher engine loading $\left(G_{p}=6 \mathrm{~kg} / \mathrm{h}\right)-$ Fig. 4 . As shown, lower exhaust gas smokiness level was noted for all the ceramic coatings. As was expected, the application of heat insulated heads resulted in increasing exhaust gas temperature within the whole range of the engine operational loads.
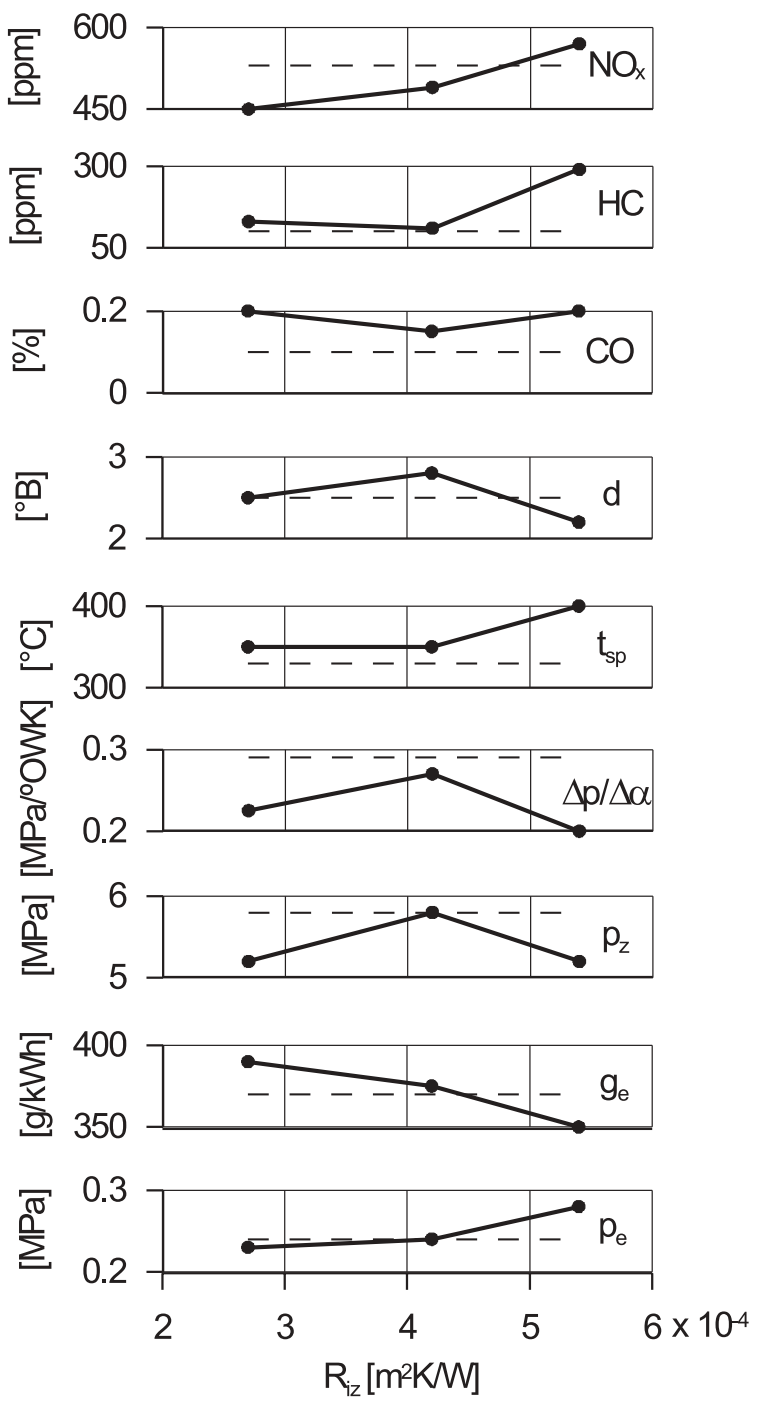

Fig. 3 Influence of heat resistance of insulating coatings on piston heads on working parameters of engine; $n=2200 \mathrm{rpm}, G_{p}=3 \mathrm{~kg} / \mathrm{h}$. Broken line - values for piston without coating.

Generally, for all the insulated pistons, the maximum speed of combustion pressure growing in the cylinder and maximum combustion pressure decreased. Furthermore, we can see clearly the relation between the hardness of engine running and the heat resistance coefficient. The higher is the heat resistance of the piston head insulating coating (less heat flows away from the combustion chamber through the piston and rings to the cylinder sleeve and to the cooling system), the lower are values of running hardness $(\Delta \mathrm{p} / \Delta \alpha)$. It can result from a lower heat evolution speed during the first phase of combustion (kinetic combustion) and elongation of the total combustion period (lower temperature in cylinder). Such interpretation is justified by the results of measurements of unburned hydrocarbons emission (increase for pistons with heat insulating coatings) and nitric oxides (decrease for heat insulated pistons). The amount of carbon monoxide was slightly higher in case of the heat insulated pistons. 

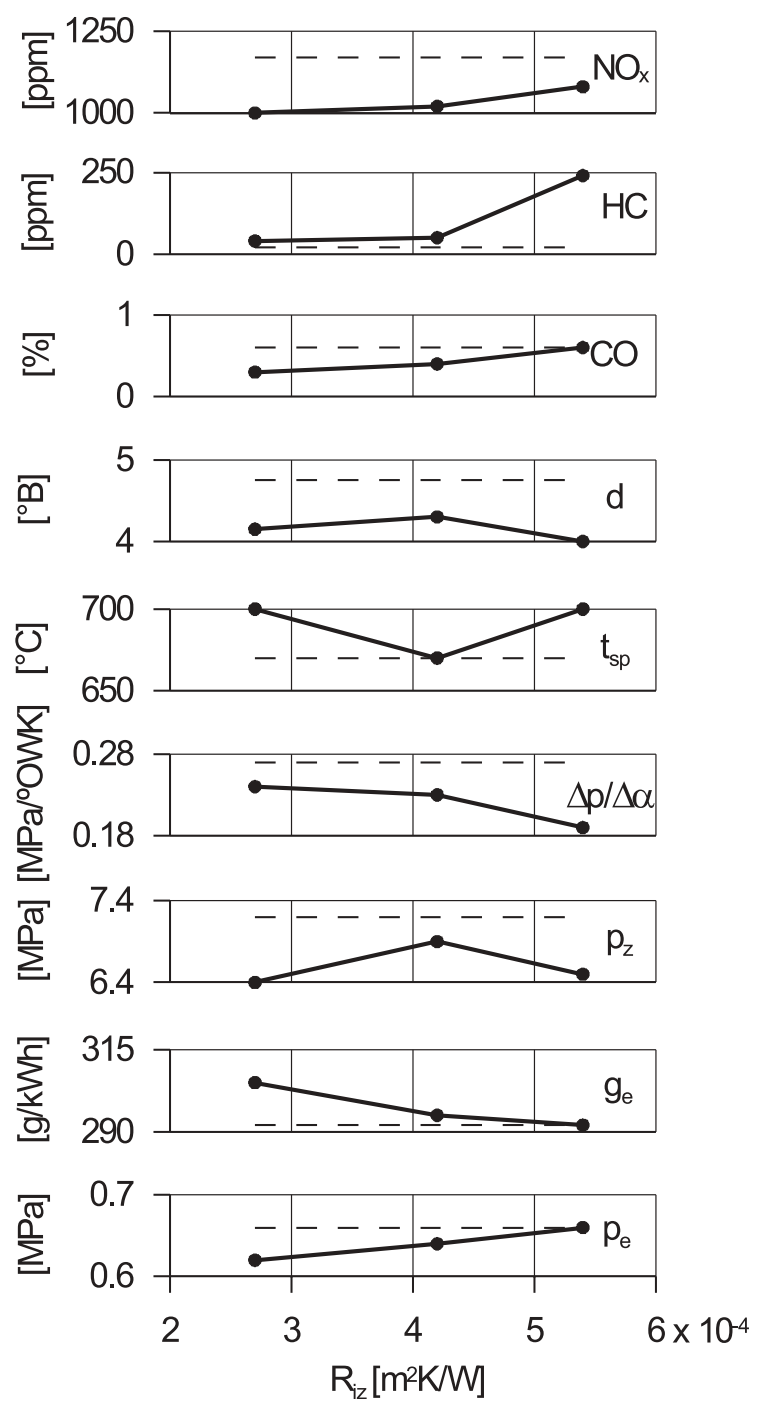

Fig. 4 Influence of heat resistance of insulating coatings on piston heads on working parameters of engine; $n=2200 \mathrm{rpm}, G_{p}=6 \mathrm{~kg} / \mathrm{h}$. Broken line - values for piston without coating.

The analysis of relations obtained for a lower rotational speed $n=1600$ rpm (Figs. 5 and 6 ) indicates that, regarding running economy, the tendencies noted at the nominal rotational speed remained. However, the effect of the increase of heat resistance of the piston head material on the fuel consumption increase at high loads and decrease at low loads is evident.

These results confirm clearly the results achieved by G. Woschni $[12,13]$ and others $[6,7]$. The reason for such results may be both more intensive carrying away of heat through the piston head within the range of higher temperature (high loading) and prolonged combustion period [2].

For two heat-insulated pistons maximum combustion pressure at high loads reached higher values (at $n=2200 \mathrm{rpm}$ ).
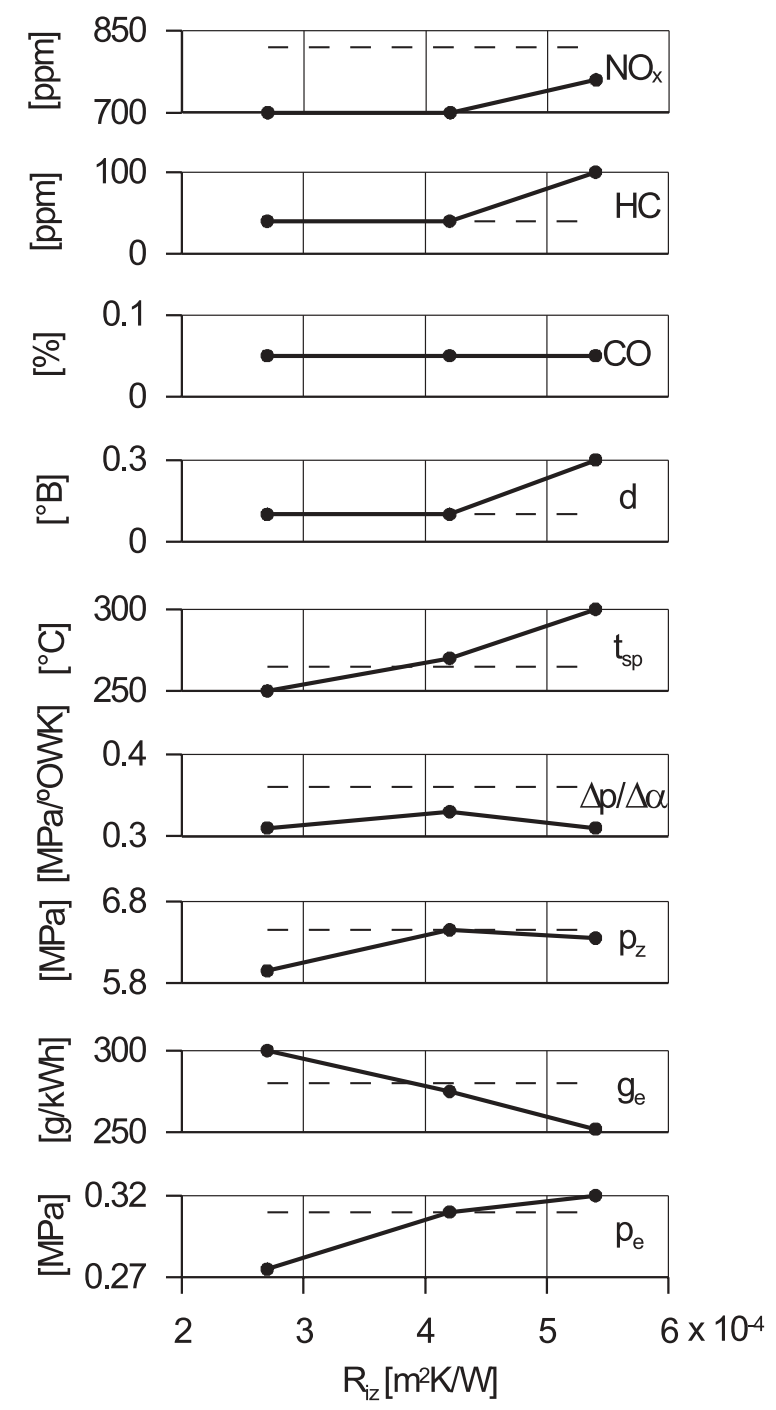

Fig. 5 Influence of heat resistance of insulating coatings on piston heads on working parameters of engine; $n=1600 \mathrm{rpm}, G_{p}=2 \mathrm{~kg} / \mathrm{h}$. Broken line - values for piston without coating.

Since there is no clear relevance to the heat resistance value, explanation of this problem on the basis of the present investigation is not possible.

\section{Conclusion}

The presented results of study of the engine with piston heads covered with ceramic coatings of diverse heat resistance permit to conclude that:

- Application of heat-insulating coatings did not improve running economy of the engine, since a general increase of fuel consumption per unit was noted. In one case only, for a piston having the highest heat resistance coefficient, fuel consumption was lower; it occurred within the range of low and mean loading. 

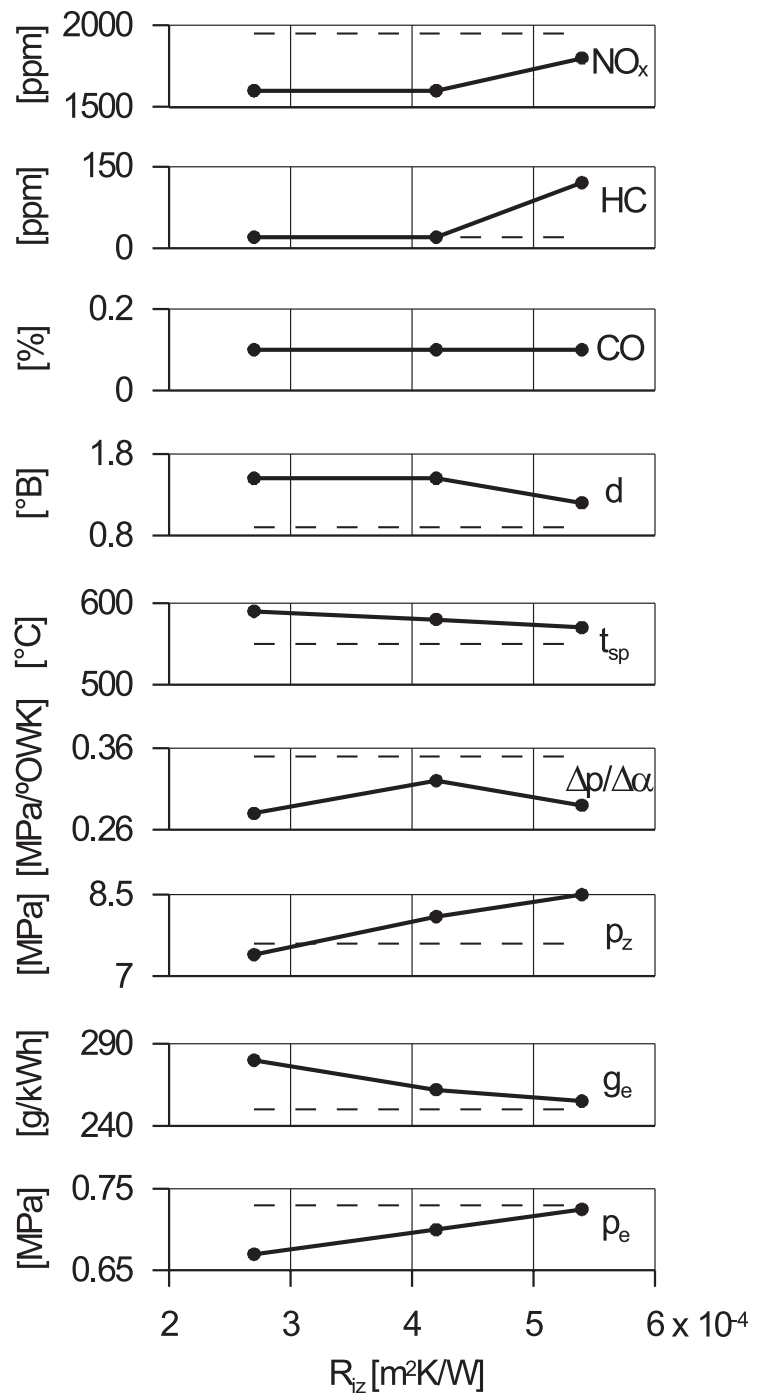

Fig. 6 Influence of heat resistance of insulating coatings on piston heads on working parameters of engine; $n=1600 \mathrm{rpm}, G_{p}=4.5 \mathrm{~kg} / \mathrm{h}$. Broken line - values for piston without coating.

- Formation of combustion indicators depends on heat resistance of the deposited ceramic coatings. The higher the heat resistance of the layer, the lower the values of maximum combustion pressure and of running hardness $(\Delta p / \Delta \alpha)$. It has a connection with the reduction of heat evolution speed as well as lower maximum temperature in the cylinder. A self-ignition delay period is shorter in case of the applied ceramic coatings. The lowest values of delay were achieved at low values of heat resistance. It can be caused by reduction of speed and increase of injection time at higher temperature in the cylinder.

- Application of the heat-insulating ceramic coatings resulted, at a lower rotational engine speed, in increasing smokiness of exhaust gas, while, at a nominal rotational speed, smokiness of exhaust gas was lower. The emission of unburned hydrocarbons and carbon monoxide increases. It must be attributed to the incomplete and deficient combustion. Concentration of nitric oxide in exhaust gas decreased within the whole range of the engine loading. It is due to the reduction of maximum temperature in the cylinder.

- The temperature of engine exhaust gas grows when the heat resistance of the heat-insulating ceramic coatings on the piston heads increases.

- Analysing the influence of the heat-insulating coatings made of $\mathrm{ZrO} 2$ we can also consider a possibility of catalytic effect of this compound on the combustion process. It could apply particularly to the first phase of combustion - reducing the self-ignition delay.

\section{Notation}

Finally, for analysis of the results the following indicators were assumed:

displacement of injector needle [mm]

working medium pressure [bar]

fuel pressure before injector [bar]

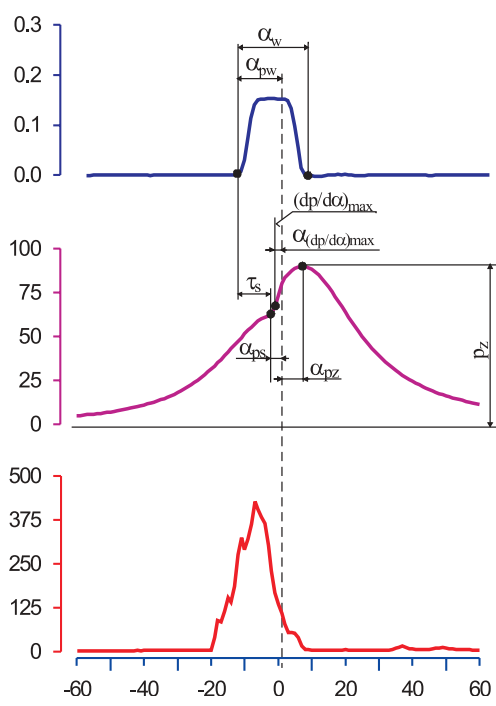

crank angle $\left[{ }^{\circ} \mathrm{OWK}\right.$ in relation to TDC]

$\tau_{\mathrm{s}} \quad-$ fuel self-ignition delay, ${ }^{\circ} \mathrm{OWK}$,

$t_{s p} \quad$ - exhaust gas temperature in the cylinder, ${ }^{\circ} \mathrm{C}$

$p_{z} \quad$ - maximum combustion pressure, $\mathrm{MPa}$,

$p_{e} \quad-$ mean effective pressure, $\mathrm{MPa}$

$T_{\max } \quad$ - maximum combustion temperature in the cylinder, $\mathrm{K}$, $(d p / d \alpha)_{\max }-$ maximum speed of combustion pressure growing, $\mathrm{MPa} /{ }^{\circ} \mathrm{OWK}$,

$\Delta p / \Delta \alpha-$ mean speed of combustion pressure growing, $\mathrm{MPa} /{ }^{\circ} \mathrm{OWK}$,

$X_{\text {imax }}$ - maximum value of heat evolution indicator, $\left(d X_{j} / \Delta \alpha\right)_{\max }$ - maximum speed of heat absorption by working agent, $1 /{ }^{\circ} \mathrm{OWK}$,

$X_{\text {chmax }}$ - maximum value of cooling losses coefficient,

$\alpha_{p z} \quad$ - angle corresponding to the maximum combustion pressure, ${ }^{\circ} \mathrm{OWK}$ in relation to TDC

$\alpha_{\text {chmax }}$ - angle corresponding to the maximum value of cooling losses coefficient, in ${ }^{\circ} \mathrm{OWK}$ in relation to TDC, 
$\alpha_{\text {Tmax }}$ - angle corresponding to the maximum temperature of the agent in cylinder, in ${ }^{\circ} \mathrm{OWK}$ in relation to TDC

$\alpha(d p / d \alpha)_{\max }$ - angle corresponding to the maximum speed of combustion pressure growing, in ${ }^{\circ} \mathrm{OWK}$ in relation to TDC $\alpha_{\text {Ximax }}$ - angle corresponding to the maximum value of heat evolution indicator, ${ }^{\circ} \mathrm{OWK}$ in relation to TDC

$\alpha_{(d X i / d \alpha) \max }-$ angle corresponding to the maximum speed of heat absorption, ${ }^{\circ} \mathrm{OWK}$ in relation to TDC

\section{References}

[1] ALKIDAS, A., C.: Experiments with Uncooled Single-Cylinder Open-Chamber Diesel. SAE Transactions 1987, No. 870020

[2] ALKIDAS, A., C.: Performance and Emission Achievements with an Uncooled Heavy-Duty Single-Cylinder Diesel Engine. SAE Transactions 1989, No. 890144

[3] CISEK, J., MRUK, A., SZLACHTA, Z.: Efekty zastosowania ceramicznej powtoki na denku ttoka silnika wysokoprężnego. IV Sympozjum „Silniki spalinowe w zastosowaniach wojskowych”, Jurata 1999, s.87-96.

[4] CISEK, J., MRUK, A., SZLACHTA, Z.: Wpływ termoizolacji denka tłoka na własności silnika wysokoprężnego. Teka Komisji Naukowo-Problemowej Motoryzacji PAN O/Kraków 15, 1998, s.105-120.

[5] DICKEY, D., W.: The Effect of Insulated Combustion Chamber Surfaces on Directed Diesel Engine Performance, Emissions and Combustion. SAE Transactions 1989, No. 890292.

[6] ENOMOTO, Y., FURUHAMA, S., TAKAI: Heat Transfer on the Ceramic Combustion Chamber Wall of Diesel Engine. CIMAC' 87, ref. D-33, Warszawa 1987.

[7] ENOMOTO, Y., FURUHAMA, S.: Heat Transfer to Wall of Ceramic Combustion of Internal Combustion Engine. Bulletin of JSNM 29, $\mathrm{nr} 250,1986$.

[8] HUANG, J., C., BORMAN., G., L.: Measurements of Instantaneous Heat Flux to Metal and Ceramic Surfaces in a Diesel Engine. SAE Transactions 1987, No 870155

[9] MRUK, A.: Badania nad zastosowaniem termoizolacyjnych powłok ceramicznych na bazie ZrO2 w budowie silników spalinowych. Seria Mechanika. Monografia nr 198. Wydawnictwo Politechniki Krakowskiej, Kraków 1995.

[10] MRUK, A.: Właściwości silnika z tłokami pokrytymi powłokami termoizolacyjnymi. Materiały konferencji KONMOT’ 94, t.2, Kraków - Raba Niżna 1994, s.273-278.

[11] SZLACHTA, Z., MRUK, A., CISEK J.: Wptyw termoizolacji denka ttoka na toksyczność spalin silnika wysokoprężnego. Teka Komisji Naukowo-Problemowej Motoryzacji PAN O/Kraków 15, 1998, s.93-103.

[12] WOSCHNI, G., HUBER, K.: The influence of Soot Deposits on Combustion Chamber Walls on Heat Losses in Diesel Engines. SAE Transactions 1991, No 910297.

[13] WOSCHNI, G., KOLESA, K., SPINDER, W.: Isolierung der Brennraumwande - Ein lohnendes Entwicklungsziel bei Verbrennungsmotoren ?. Motortechnische Zeitschrift 47, n. 12, 1986, s. 495-500. 